26. JG. Carter, SW. Phillips SM. Gayadeen, "Implementing Intelligence Led Policing: An Application of LooseCoupling Theory", Journal of Criminal Justice, 2014. 42: 433-442.

27. Masterstudiengang : Öffentliche Verwaltung - Polizeimanagement (Publik Administration - Police Management) - Modulhandbuch. Münster : Deutsche Hochschule der Polizei, 2014. 102 S.

28. Nill M. Blue courage - servingand protecting those who... [Electronic resource] : website. - Accesses mode: http://bluecourage.com. - Title from the screen.

Цитування на цю статтю:

Римик ВР, Вербовий ВП. Сутність професійно-прикладної фізичної підготовки майбутніх поліцейських. Вісник Прикарпатського університету. Серія: Фізична культура. 2019 Листоп 27; 34: 93-103

\begin{tabular}{|c|c|}
\hline Відомості про автора: & Information about the author: \\
\hline $\begin{array}{l}\text { Римик Владислав Романович - Аспірант, Прикар- } \\
\text { патський національний університет імені Василя } \\
\text { Стефаника. ( Івано-Франківськ, Україна) }\end{array}$ & $\begin{array}{l}\text { Rymyk Vladislav - post-graduate student, Vasyl } \\
\text { Stefanyk Precarpathian National University ( Ivano- } \\
\text { Frankivsk, Ukraine) }\end{array}$ \\
\hline \multicolumn{2}{|l|}{$\begin{array}{l}\text { e-mail: scific1996@ gmail.com } \\
\text { https://orcid.org/0000-0001-6029-0511 }\end{array}$} \\
\hline $\begin{array}{l}\text { Вербовий Василь Петрович - кандидат наук з фі- } \\
\text { зичного виховання і спорту, Прикарпатський фа- } \\
\text { культет (м. Івано-Франківськ) Національна ака- } \\
\text { демія внутрішніх справ } \quad \text { (м. Івано-Франківськ, } \\
\text { Україна). }\end{array}$ & $\begin{array}{l}\text { Verbovyi Vasyl - candidate of physical training and } \\
\text { sport, Precarpathian department (Ivano-Frankivsk) } \\
\text { National Academy of Internal Affairs (Ivano- } \\
\text { Frankivsk, Ukraine). }\end{array}$ \\
\hline $\begin{array}{l}\text { e-mail: verbovuyif@ukr.net } \\
\text { https://orsid.org/0000-0002-5004-4170 }\end{array}$ & \\
\hline
\end{tabular}

УДК 159.942.37.04.612.7

doi: 10.15330/fcult.34.103-111 Леонід Мосійчук

\title{
ВИХОВАННЯ В МОЛОДШИХ ШКОЛЯРІВ ІНТЕРЕСУ ДО ЗАНЯТЬ З ФІЗИЧНОГО ВИХОВАННЯ У СИСТЕМІ “ШКОЛА-СІМ'Я”
}

\begin{abstract}
Мета дослідження - визначити комплекс психолого-педагогічних умов, щчо сприяють ефективному вихованню в молодших школярів інтересу до занять фізичними вправами та розробити методику їх реалізації в системі “икола-сім'я”. Методи й організація дослідження. Для реалізації поставленої мети були використані наступні методи дослідження: теоретичний аналіз та узагальнення спеціальних інформаційних джерел; педагогічне спостереження за активністю учнів на заняттях; анкетування школярів та їхніх батьків, педагогічний експеримент; методи математичної статистики. Педагогічний експеримент тривав шість місяиів. Результати. Аналіз передової практики шкіл та численних наукових досліджень свідчить, щзо процес формування в учнів потреби у фізичному вдосконаленні починається щзе у ранньому шкільному віці з виховання інтересу до фізичних вправ. Поряд з ичим наявні методичні розробки не включають в себе реалізацію повного комплексу психолого-педагогічних чинників, щуо сприяють зацікавленості дітей до занять. Зокрема виявлено, що теоретики та практики не наділяють належної уваги позакласним та позашкільним формам фізичного виховання, в реалізації яких особливу роль відіграє сімейне оточення дитини. Висновок. Педагогічний експеримент показав, щзо комплексна реалізація відповідних психолого-педагогічних чинників при тісній співпраці школи та сім' $і$ сприяє значному підвищенню інтересу школярів до різних форм фізичного виховання та суттєво підвищує їхню активність на заняттях.
\end{abstract}

Ключові слова: фізичне виховання, інтерес, молодші школярі, психолого-педагогічні умови, система “икола-сім'я”.

The purpose of the study is to identify a complex of psychological and pedagogical conditions that contribute to the effective education of younger students of interest in exercise and to develop a method for their implementation in the school-family system.

Research methods and organization. The experiment was attended by students of 3rd and 3rd grades of secondary school. The first one was the experimental group of subjects (19 students), the second one was the control group (18 students). In the experimental group, classes were conducted according to the methodology we developed, in the control group - according to the traditional one. To achieve this goal, the following 
research methods were used: theoretical analysis and generalization of special information sources; pedagogical observation of the activity of students in the classroom; questioning of students and their parents, pedagogical experiment; methods of mathematical statistics. The pedagogical experiment lasted six months.

Results. The analysis of best practices of schools and numerous scientific researches shows that the process of formation of the need for physical perfection of students begins at an early school age with the cultivation of interest in physical exercises. In addition, the available methodological developments do not include the implementation of a full range of psychological and pedagogical factors that contribute to the interest of children in the classroom. In particular, it has been found that theorists and practitioners do not pay proper attention to extracurricular and extracurricular forms of physical education, in which the child's family environment plays a special role.

Conclusions. Only about $20 \%$ of younger students and their parents were found to have a high level of interest in exercising. The pedagogical experiment showed that the complex implementation of relevant psychological and pedagogical factors in close cooperation between school and family contributes to a significant increase in the interest of students in various forms of physical education and significantly increases their activity in the classroom.

Keywords: physical education, interest, physical education, psychological and pedagogical conditions, physical activity, school-family system.

Постановка проблеми та аналіз результатів останніх досліджень. Кінцева мета шкільного фізичного виховання - озброїти випускників знаннями, вміннями та навичками ефективної організації самостійних занять фізичними вправами, сформувати мотивацію та звичку до систематичних тренувань. Необхідною передумовою іiі досягнення $є$ виховання у школярів інтересу до фізичних вправ $[9,10,11]$. За даними наукових досліджень, значна частина учнів, маючи навіть достатньо високий освітній рівень, не хоче та не вміє покращувати фізичну працездатність та турбуватись про своє здоров'я. Одна з серйозних проблем сучасної школи - ослаблення інтересу учнів до фізичної культури. Тому першочерговим завданням середньої освіти є виховання у дитини ще в молодших класах зацікавленості до занять фізичними вправами. Проведений нами аналіз спеціальної літератури $[1,2,4,5,7,8,11]$ виявив, що практичні рекомендації у вирішенні цього завдання не включають в себе реалізацію повного комплексу психолого-педагогічних умов формування інтересу до рухової активності. Серед них найбільшою прогалиною $є$ організація роботи з батьками учнів у цьому напрямі, тобто система "школа-сім'я" не працює належним чином. 3 цих причин інтерес школярів до занять фізичними вправами не є достатньо високим. Цим і було зумовлено проведення даного дослідження.

Робота виконана згідно плану НДР Тернопільського національного педагогічного університету ім. В. Гнатюка.

Мета дослідження - визначити комплекс психолого-педагогічних умов, що сприяють ефективному вихованню в молодших школярів інтересу до занять фізичними вправами та розробити методику їх реалізації в системі “школа-сім'я”.

Методи й організація дослідження. Для реалізації мети були використані наступні методи дослідження: теоретичний аналіз та узагальнення спеціальних інформаційних джерел; педагогічне спостереження за активністю учнів на заняттях; анкетування школярів та їхніх батьків, педагогічний експеримент; методи математичної статистики. В експерименті прийняли участь школярі 3-а та 3-б класів загальноосвітньої середньої школи. Перший з них був експериментальною групою досліджуваних (19 учнів), інший - контрольною (18 учнів). Педагогічний експеримент тривав шість місяців.

Результати дослідження і дискусія. 3 метою визначення ступеня зацікавленості школярів у заняттях фізичними вправами, а також ставлення батьків до фізичного виховання своїх дітей нами були розроблені відповідні анкети (табл. 1, 2). 
Мосійчук Леонід. Виховання в молодших школярів інтересу до занять з фізичного виховання у системі ...

Таблиция 1

Ставлення учнів до занять на початку експерименту

\begin{tabular}{|c|c|c|c|c|c|c|c|}
\hline \multirow{2}{*}{\multicolumn{2}{|c|}{ Питання }} & \multicolumn{3}{|c|}{ ЕГ (19 учнів) } & \multicolumn{3}{|c|}{ КГ (18 учнів) } \\
\hline & & учні & $\%$ & бали & учні & $\%$ & бали \\
\hline \multirow[t]{4}{*}{1} & $\begin{array}{l}\text { Чи подобаються тобі заняття } 3 \text { фізичного } \\
\text { виховання та спорту? }\end{array}$ & & & & & & \\
\hline & дуже (2 бали) & 4 & 21 & 8 & 3 & 17 & 6 \\
\hline & не дуже (1 бал) & 10 & 53 & 10 & 11 & 61 & 11 \\
\hline & вони нецікаві та непотрібні (0 балів) & 5 & 26 & 0 & 4 & 22 & 0 \\
\hline \multirow[t]{3}{*}{2} & Чи виконусш ти ранкову зарядку? & & & & & & \\
\hline & щоденно (2 бали) & 2 & 10 & 4 & 3 & 16,5 & 6 \\
\hline & інколи (1 бал) & 3 & 16 & 3 & 5 & 28 & 5 \\
\hline & не виконую (0 балів) & 14 & 74 & 0 & 10 & 55,5 & 0 \\
\hline \multirow[t]{3}{*}{3} & $\begin{array}{l}\text { Чи стомлюсшся ти на уроках сидячи за } \\
\text { партою? }\end{array}$ & & & & & & \\
\hline & так (0 балів) & 15 & 79 & 0 & 13 & 72 & 0 \\
\hline & ні (1 бал) & 4 & 21 & 4 & 5 & 28 & 5 \\
\hline \multirow[t]{5}{*}{4} & $\begin{array}{l}\text { Як переважно ти проводиш час після } \\
\text { школи? }\end{array}$ & & & & & & \\
\hline & $\begin{array}{l}\text { виконую малорухливу роботу (комп’ютер, } \\
\text { уроки, телевізор) (0 балів) }\end{array}$ & 9 & 47 & 0 & 8 & 44 & 0 \\
\hline & допомагаю батькам по господарству (1 бал) & 7 & 37 & 7 & 8 & 44 & 8 \\
\hline & $\begin{array}{l}\text { займаюсь фізичними вправами (футбол, } \\
\text { велосипед, перекладина інше) (2 бали) }\end{array}$ & 6 & 31 & 12 & 5 & 28 & 10 \\
\hline & відвідую спортивну секцію (3 бали) & 3 & 16 & 9 & 2 & 11 & 6 \\
\hline \multirow[t]{4}{*}{5} & $\begin{array}{l}\text { Ти виконусш домашні завдання } 3 \text { фізич- } \\
\text { ного виховання }\end{array}$ & & & & & & \\
\hline & так, регулярно (2 бали) & 3 & 16 & 6 & 2 & 11 & 4 \\
\hline & інколи (1 бал) & 6 & 31 & 6 & 5 & 28 & 5 \\
\hline & ні (0 балів) & 10 & 53 & 0 & 11 & 61 & 0 \\
\hline \multirow[t]{3}{*}{6} & Чи с у тебе дома спортивний куток? & & & & & & \\
\hline & $\epsilon(1$ бал) & 3 & 16 & 3 & 3 & 17 & 3 \\
\hline & немає (0 балів) & 16 & 84 & 0 & 15 & 83 & 0 \\
\hline \multirow[t]{4}{*}{7} & $\begin{array}{l}\text { Батьки цікавляться твоїми успіхами } 3 \\
\text { фізичного виховання? }\end{array}$ & & & & & & \\
\hline & не цікавляться (0 балів) & 13 & 68 & 0 & 11 & 61 & 0 \\
\hline & цікавляться лише оцінками (1 бал) & 3 & 16 & 3 & 4 & 22 & 4 \\
\hline & $\begin{array}{l}\text { цікавляться та спонукають до виконання } \\
\text { фізичних вправ (2 бали) }\end{array}$ & 3 & 16 & 6 & 3 & 17 & 6 \\
\hline \multirow[t]{4}{*}{8} & Твої батьки виконують фізичні вправи? & & & & & & \\
\hline & ні (0 балів) & 12 & 63 & 0 & 11 & 61 & 0 \\
\hline & інколи (1 бал) & 4 & 21 & 4 & 5 & 28 & 5 \\
\hline & регулярно (2 бали) & 3 & 16 & 6 & 2 & 11 & 4 \\
\hline & Загальна сума балів & & & 91 & & & 88 \\
\hline & Відносний бал & & & 4,789 & & & $\mathbf{4 , 8 8 8}$ \\
\hline
\end{tabular}


Ставлення батьків до фізичного виховання власних дітей на початку експерименту (опитано 37 сімей)

\begin{tabular}{|c|c|c|c|}
\hline \multicolumn{2}{|r|}{ Питання } & \multirow[t]{2}{*}{$\begin{array}{l}\text { Кількість } \\
\text { відповідей }\end{array}$} & \multirow[t]{2}{*}{ \% відповідей } \\
\hline 1 & $\begin{array}{l}\text { Що на вашу думку с найважливішим чинником } \\
\text { здоров'я та нормального фізичного розвитку вашої } \\
\text { дитини? }\end{array}$ & & \\
\hline & загартування & 6 & 16 \\
\hline & нормальне харчування & 10 & 27 \\
\hline & спадковість & 24 & 65 \\
\hline & фізична праця & 15 & 40 \\
\hline & фізичне виховання та спорт & 8 & 21 \\
\hline & лікарські засоби (масаж, фармація) & 4 & 11 \\
\hline & ваш варіант (вкажіть): & 0 & \\
\hline \multirow[t]{5}{*}{2} & $\begin{array}{l}\text { Яку роль фізичне виховання та спорт відіграс для } \\
\text { вашої дитини? }\end{array}$ & & \\
\hline & відпочинок від розумової діяльності & 15 & 40 \\
\hline & нормальний фізичний розвиток, міцнення здоров’я. & 8 & 21 \\
\hline & щоб був кращим у спорті & 9 & 24 \\
\hline & ніякої & 10 & 27 \\
\hline \multirow[t]{3}{*}{3} & Чи потрібно дитині виконувати ранкову зарядку? & & \\
\hline & так & 15 & 40 \\
\hline & ні & 22 & 59 \\
\hline \multirow[t]{3}{*}{5} & $\begin{array}{l}\text { Чи потрібні домашні завдання } 3 \text { фізичного } \\
\text { виховання? }\end{array}$ & & \\
\hline & так & 10 & 27 \\
\hline & ні & 27 & 73 \\
\hline \multirow[t]{4}{*}{6} & $\begin{array}{l}\text { Чи турбуєтесь ви про те, щоб ваша дитина } \\
\text { виконувала фізичні вправи до та після школи? }\end{array}$ & & \\
\hline & так, віддали дитину у спортивну секцію & 6 & 16 \\
\hline & $\begin{array}{c}\text { так, дбаєм про створення домашнього спортивного } \\
\text { обладнання та інвентаря, спонукаєм дитину до } \\
\text { виконання фізичних вправ }\end{array}$ & 5 & 13 \\
\hline & ні & 31 & 84 \\
\hline \multirow[t]{3}{*}{7} & $\begin{array}{l}\text { Чи займасться хтось із сімейного оточення вашої } \\
\text { дитини систематичним фізичним вихованням та } \\
\text { спортом? }\end{array}$ & & \\
\hline & так (вкажіть хто і чим): & 9 & 24 \\
\hline & ні & 28 & 76 \\
\hline \multirow[t]{3}{*}{9} & $\begin{array}{l}\text { До якого ряду шкільних предметів ви відносите } \\
\text { фізичне виховання? }\end{array}$ & & \\
\hline & до основних & 8 & 21 \\
\hline & до другорядних & 29 & 78 \\
\hline \multirow[t]{3}{*}{10} & $\begin{array}{c}\text { Чи вважаєте ви, що фізичне виховання може бути } \\
\text { шкідливим для здоров'я та навчально-виховного } \\
\text { процесу вашої дитини? }\end{array}$ & & \\
\hline & так & 6 & 16 \\
\hline & ні & 31 & 84 \\
\hline
\end{tabular}


Опитування на початку експерименту виявило недостатній інтерес більшості школярів і їхніх сімей до виконання фізичних вправ та підтвердило дані, що лише близько 20\% батьків цікавляться фізичним вихованням своїх дітей [9].

Для визначення безпосередньої рухової активності учнів на заняттях нами розроблено відповідні критерії оцінювання.

\begin{tabular}{|c|l|}
\hline Бали & \multicolumn{1}{|c|}{ Критерії оцінювання активності учнів на заняттях } \\
\hline $\mathbf{4}$ & $\begin{array}{l}\text { висока активність - учень із бажанням виконує усі завдання вчителя та проявляє } \\
\text { ініціативу, допитливість, наполегливість, сміливість, рішучість, витримку при } \\
\text { подоланні труднощів }\end{array}$ \\
\hline $\mathbf{3}$ & $\begin{array}{l}\text { середня активність - учень якісно виконує усі завдання та вказівки вчителя, про те у } \\
\text { його діях не спостерігається активної участі; він машинально виконує вказівки } \\
\text { вчителя без належної ініціативи та допитливості. }\end{array}$ \\
\hline $\mathbf{2}$ & $\begin{array}{l}\text { низька активність - учень ігнорує вказівки вчителя, уникає виконання завдань без } \\
\text { його нагляду, проявляє байдужість до рухових завдань. }\end{array}$ \\
\hline $\mathbf{1}$ & $\begin{array}{l}\text { активність відсутня - учень присутній на занятті, але не виявляє бажання } \\
\text { виконувати фізичні вправи, виконує функцію помічника }\end{array}$ \\
\hline $\mathbf{0}$ & учень відсутній на занятті без поважної причини \\
\hline
\end{tabular}

Педагогічне спостереження на практичних заняттях також показало недостатню активність учнів. Лише близько 20\% дітей були високоактивними (табл. 3).

Таблиця 3

Рівень активності учнів до експерименту

\begin{tabular}{|c|c|c|c|c|c|c|c|c|c|c|}
\hline учні & \multicolumn{2}{|c|}{ бали } & \multicolumn{2}{|c|}{1} & \multicolumn{2}{c|}{ 2 } & \multicolumn{2}{c|}{3} & \multicolumn{2}{c|}{4} \\
\hline ЕГ (19) & 3 & $16 \%$ & 4 & $21 \%$ & 5 & $26 \%$ & 3 & $16 \%$ & 4 & $21 \%$ \\
\hline КГ (18) & 2 & $11 \%$ & 4 & $22 \%$ & 4 & $22 \%$ & 4 & $22 \%$ & 3 & $16 \%$ \\
\hline
\end{tabular}

Для вирішення виявленої проблеми ми розробили експериментальну методику виховання у молодших школярів інтересу до занять фізичними вправами. В іiі основу лягло положення про те, що діти позитивно ставляться лише до того, що викликає в них позитивні емоції та приносить радість $[7,6,9]$. Такі можливості мають наступні психолого-педагогічні чинники (рис. 1).

Велике значення під час формування інтересу школярів до систематичних занять фізичними вправами відіграє сім'я кожної дитини. Функції батьків у фізичному вихованні дітей полягають: 1) у належній організації позашкільного фізичного виховання (виконання ранкової гімнастики і домашніх завдань, організація дозвілля дітей за місцем проживання, залучення до спортивних секцій, дотримання правил особистої гігієни та загартування); 2) в особистому прикладі систематичних занять фізичним вихованням та спортом, дотриманні здорового способу життя та зацікавленості до успіху дітей. Відповідно до цих функцій батьків при налагодженні співпраці сім’ї та школи наша методика передбачала реалізацію таких завдань:

1. Переконати батьків у необхідності систематичного виконання фізичних вправ та озброїти їх необхідними уміннями та навичками належної організації фізичного виховання дітей в домашніх умовах. Для цього ми періодично (два рази на місяць) проводили зустрічі з батьками, на яких подавали інформацію про важливість фізичних вправ, надавали консультації щодо правильної організації фізичного виховання поза 
школою та створення належних матеріально-технічних умов для занять удома, повідомляли про наявний фізичний стан дітей.

2. Залучити батьків до рухової активності разом з дітьми. 3 цією метою ми організовували змагання сімейних команд (естафети та рухливі ігри, вікторини, конкурси).

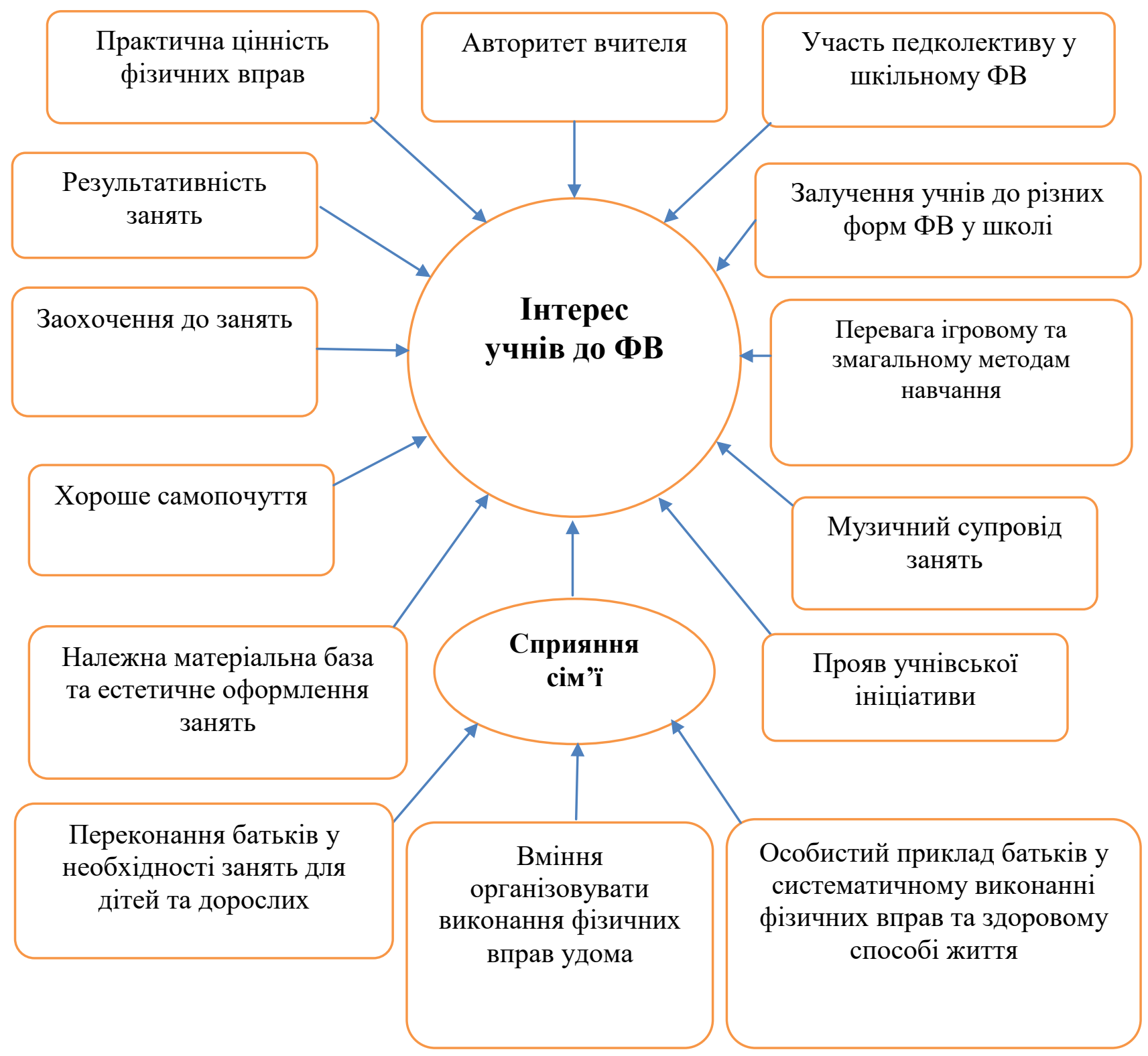

Puc 1. Психолого-педагогічні чинники формування у школярів інтересу до занять фізичними вправами в системі “школа-сім'я”.

Після проведення педагогічного експерименту ми провели повторне опитування школярів на предмет їхнього ставлення до занять з фізичного виховання та спорту (табл. 4). 
Мосійчук Леонід. Виховання в молодших школярів інтересу до занять з фізичного виховання у системі ...

Ставлення учнів до занять після педагогічного експерименту

Таблиия 4

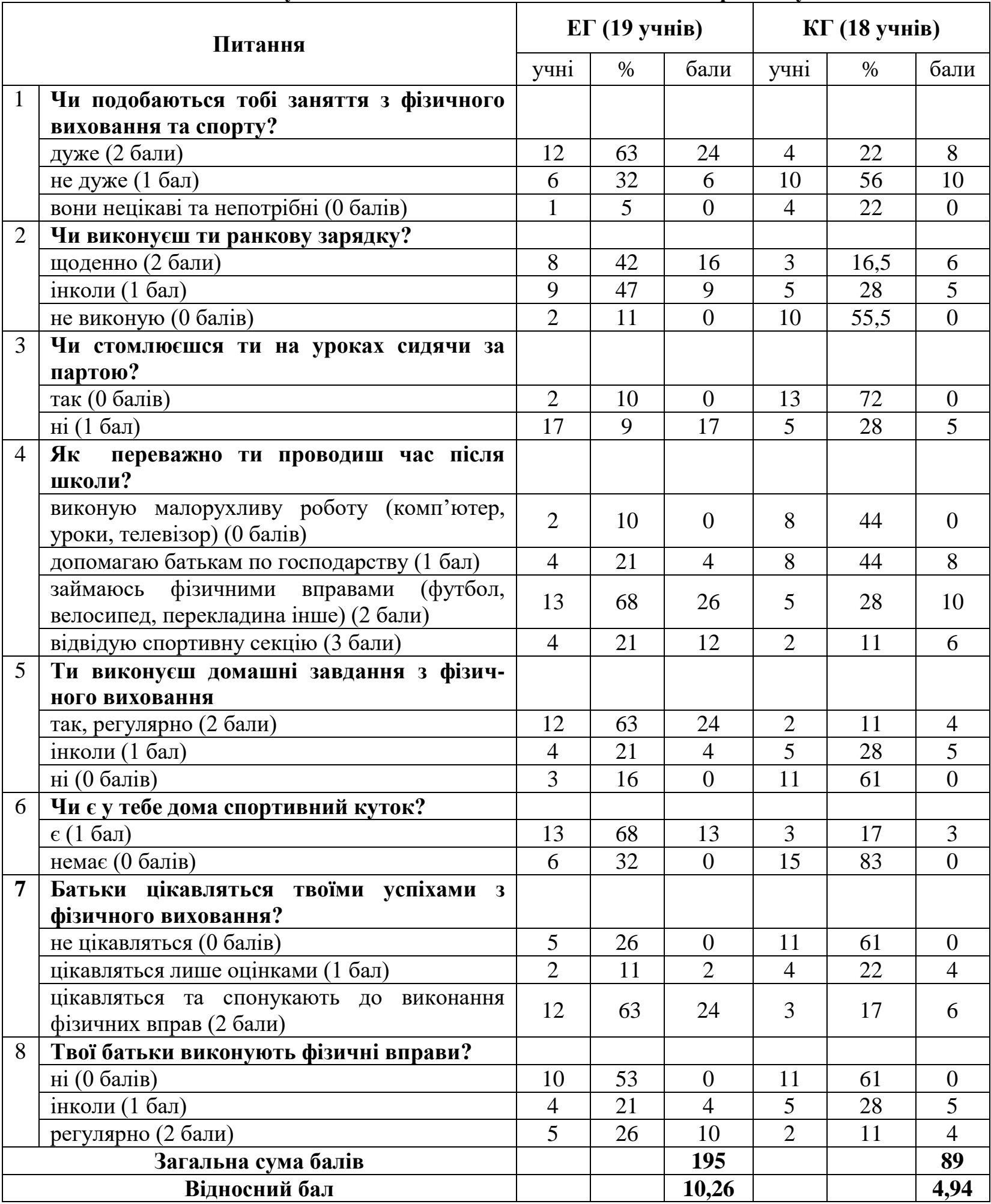

Повторне опитування досліджуваних показало значне підвищення інтересу до занять у школярів ЕГ, у той час як у КГ ставлення до фізичних вправ практично не змінилось. Позитивні зрушення були виявлені також при спостереженні за активністю дітей на заняттях (табл. 5). 
Рівень активності учнів після експерименту

\begin{tabular}{|c|c|c|c|c|c|c|c|c|c|c|}
\hline учні & \multicolumn{2}{|c|}{ оали } & \multicolumn{2}{|c|}{ 1 } & \multicolumn{2}{|c|}{2} & \multicolumn{2}{|c|}{3} & \multicolumn{2}{|c|}{4} \\
\hline ЕГ (19) & 0 & $0 \%$ & 1 & $5 \%$ & 2 & $11 \%$ & 5 & $26 \%$ & 11 & $58 \%$ \\
\hline КГ (18) & 2 & $11 \%$ & 4 & $22 \%$ & 4 & $22 \%$ & 4 & $22 \%$ & 3 & $16 \%$ \\
\hline
\end{tabular}

Фактично усі учні ЕГ почали відвідувати заняття з фізичного виховання. Високу активність проявило на $37 \%$ школярів більше, ніж на початку експерименту, середню на 10\%, низьку - на 10\% менше, і лише 5\% дітей байдуже віднеслись до занять.

\section{Висновки.}

1. Аналіз наукової літератури та результати констатуючого експерименту вказують на актуальність проблеми виховання у школярів позитивного ставлення та інтересу до занять фізичними вправами.

2. Для ефективного виховання в молодших школярів інтересу до занять фізичними вправами потрібна комплексна реалізація відповідних психолого-педагогічних чинників, серед яких особливе місце посідає співпраця сім'ї та школи.

3. Запропонована методика вирішення проблеми виявилась ефективною, про що свідчить порівняльний аналіз результатів проведених тестувань на початку та в кінці дослідження.

1. Боднарчук О. Фізична підготовленість учнів перших класів в умовах взаємодії школи та сім’ї. Спортивна наука України. Львів: ЛДУФК, 2012. № 3 (47). с. 30-34.

2. Вільчковський ЕС, Козленко МП, Цвек СФ. Система фізичного виховання молодших школярів: [навч.-метод. посіб. для викл. та студ. вищ. навч. закл. освіти I-II рівнів акредитації]. Київ: IЗMН, 1998. 232 c.

3. Выготский ЛС. Собрание починений. Детская психология. Москва: Высшая школа; 2001. 456 с.

4. Выдрин ВМ. Неспециальное (непрофессиональное) физкультурное образование. Теория и практика физической культуры. 1995; (5-6): 15-17.

5. Іващенко ОВ. Моделювання процесу фізичного виховання школярів: монографія. Харків, ОВС, 2016. $300 \mathrm{c}$.

6. Гогунов ЕН, Мартьянов БИ. Психология физического воспитания и спорта: Учеб. пособие для студ. высш. пед. учеб. заведений Москва: Издательский центр. “Академия”; 2004. 224 с.

7. Далинина ТА, Зедгенидзезе ВЯ, Степина НМ. В мире детских эмоций: пособие для практических работников ДОУ Москва: Айрис-пресс; 2004. 160 с.

8. Пилоян РА, Суханов АД. Физическая культура как объект познания в аспекте психологической деятельности. Теория и практика физической культуры [Інтернет]. 2000 [цитовано 2018 бер 22]; 11: URL: http://lib.sportedu.ru/Press/TPFK/2000N11.

9. Шиян БМ. Теорія і методика фізичного виховання: навч. Посібник. Тернопіль: Навч. книга - Богдан. $2001.272 \mathrm{c}$.

10. Goleman D. Emotional Inteligence. New York: Bantam Books; 2006. 360 p.

11. Carlos Valiente, Jodi Swanson, Nancy Eisenberg. Linking Students' Emotions and Academic Achievement: When and Why Emotions Matter Child. Dev. 2012; 6 (2): 129-35.

\section{References}

1. Bodnarchuk O. Fizichna pidgotovlenist' uchniv pershikh klasiv v umovakh vzaiemodii shkoli ta sim'i [1 st form pupils' physical fitness in conditions of family-school interaction]. Sportivna nauka Ukraini, 2012;3(47):30-34.

2. Vil'chkovs'kij ES, Kozlenko MP, Cvek SF. Sistema fizichnogo vikhovannia molodshikh shkoliariv [Physical education system for primary school pupils], Kiev: IZMN; 1998. (in Ukrainian)

3. Vyigotskiy LS. Meeting of repentance. Child psychology. Moscow: Vyisshaya shkola; 2001. 456 p.

4. Vydrin VM. Non-special (non-professional) physical education. Theory and practice of physical culture. 1995; (5-6): 15-17.

5. Ivashchenko OV. Modeliuvannia procesu fizichnogo vikhovannia shkoliariv [Modeling of schoolchildren's physical education process]. Kharkiv: OVS; 2016. (in Ukrainian) 
6. Gogunov EN, Martyanov BI. Psychology of physical education and sports: Ucheb. posobie dlya stud. vyissh. ped. ucheb. zavedeniy Moskva: Izdatelskiy tsentr. "Akademiya"; 2004. 224 p.

7. Dalinina TA, Zedgenidzeze VYa, Stepina NM. In the World of Children's Emotions: A Handbook for Practitioners of the DOU Moscow: Ayris-press; 2004. 160 p.

8. Piloyan RA, Suhanov AD. Physical culture as an object of cognition in the aspect of psychological activity. Teoriya i praktika fizicheskoy kulturyi [Internet]. 2000 [cited 2018 бep 22].

9. Shyian BM. Theory and Methods of Physical Education: Teach: Navch. knyha - Bohdan. 2001. 272 p.

10. Goleman D. Emotional Inteligence. New York: Bantam Books; 2006. 360 p.

11. Carlos Valiente, Jodi Swanson, Nancy Eisenberg. Linking Students' Emotions and Academic Achievement: When and Why Emotions Matter Child. Dev. 2012; 6 (2): 129-35.

Цитування на цю статтю:

Мосійчук ЛВ. Виховання в молодших школярів інтересу до занять з фізичного виховання у системі “школа-сім’я”.Вісник Прикарпатського університету. Серія: Фізична культура. 2019 Листоп 27; 34: 103-111

\begin{tabular}{|c|c|}
\hline Відомості про автора: & Information about the author: \\
\hline $\begin{array}{l}\text { Мосійчук Леонід Васильович - кандидат наук з фі- } \\
\text { зичного виховання і спорту, доцент, Тернопільсь- } \\
\text { кий національний педагогічний університет імені } \\
\text { В. Гнатюка (Тернопіль, Україна) }\end{array}$ & $\begin{array}{l}\text { Mosiychuk Leonid-Candidate of Science in Physical } \\
\text { Education and Sports, Associate Professor, Ternopil } \\
\text { National Pedagogical University named after V. } \\
\text { Hnatyuk (Ternopil, Ukraine) }\end{array}$ \\
\hline $\begin{array}{l}\text { e-mail: leonid.mosiychuk@ gmail.com } \\
\text { https://orcid.org/0000-0002-2756-5795 }\end{array}$ & \\
\hline
\end{tabular}

УДК 796.011.2:796.6

doi: 10.15330/fcult.34.111-124
Дмитро Піонтковський, Богдан Мицкан, Тетяна Мицкан

\section{РОЗВИТОК ШВИДКІСНИХ І КООРДИНАЦІЙНИХ ЗДІБНОСТЕЙ СПОРТСМЕНІВ 3 ВЕЛОСИПЕДНОГО СПОРТУ ВМХ НА ЕТАПІ ПОЧАТКОВОї ПІДГОТОВКИ}

Мета. Розробити та експериментально перевірити ефективність програми розвитку швидкісних $i$ координаційних здібностей спортсменів велосипедного спорту ВМХ на етапі початкової підготовки. Методи. У ході дослідження було проведено педагогічний експеримент, який тривав протягом 3 років. На різних етапах експерименту прийняло участь 72 юних велосипедисти ВМX, 36 з яких увійшли до контрольних груп (по 12 учасників у кожній), а 36 - до основних. Очінка рівня розвитку швидкісних здібностей та абсолютних координаційних здібностей здійснювалася за допомогою рухових тестів (біг 30 м, човниковий біг 3 x10 м). Збереження вертикальної стійкості тіла визначали за допомогою тесту С.Я. Бондаревського. 3 метою акиентованого розвитку координаційних здібностей було застосовано комплекси неспецифічних для велоспорту ВМХ вправ, а саме стрибки на батуті. Мотиваційна складова велосипедистів-початківців ВМХ визначалася з використанням методик діагностики особистості на мотивачію до досягнення успіху та уникнення невдач за Т. Елерсом. Психологічний компонент програми двокомпонентного психофізичного впливу, базувався на використанні вербальних засобів психологічної підготовки спортсменів, використання методів психологічної мотивації до виконання неспецифічних вправ. Результати. Доведено, що показники розвитку досліджуваних фізичних здібностей учасників основних груп наприкінці річних макрочиклів тренування під впливом реалізаиії авторської програми вірогідно зросли у порівнянні з аналогічними показниками контрольних груп. Водночас зріс рівень вертикальної стійкості тіла велосипедистів-початківців ВМХ основних груп $i$ на останньому етапі дослідження перевищував нормативи середнього рівня, установлених для європейської популяції у віковій когорті 10-річних спортсменів. При ц̧ьому, виявлено статистично значущу різницю між середньо груповими результатами проходження змагальної дистанції 380 м учасниками основної та контрольної груп на користь юних спортсменів основних груп в усіх трьох річних макроциклах тренування. Висновок. Застосування в групах початкової підготовки спортсменів-велосипедистів ВМХ двокомпонентного психофізичного впливу на розвиток спеціальних фізичних якостей забезпечує інтенсивне удосконалення як ивидкісних $i$ координаційних здібностей, так і вертикальної стійкості, а також покращення результатів змагальної діяльності.

Ключові слова: спортсмени-велосипедисти ВМX, етап початкової підготовки, швидкісні $i$ координаційні здібності, програм двокомпонентного психофізичного впливу. 